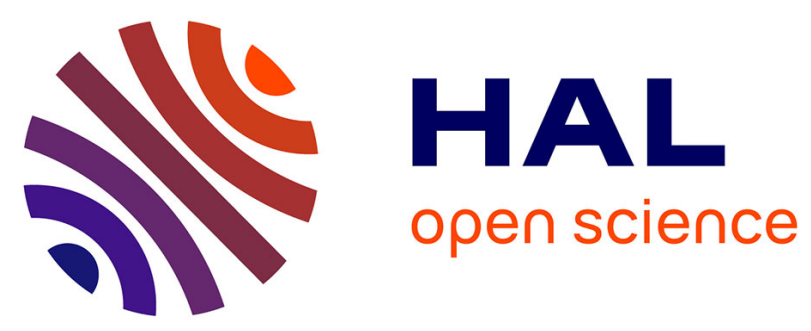

\title{
Debaryomyces hansenii, Proteus vulgaris, Psychrobacter sp and Microbacterium foliorum are able to produce biogenic amines
}

\author{
Sandra Hélinck, Marie-Claire Perello, Pawinee Deetae, Gilles de Revel, \\ Henry-Eric Spinnler
}

\section{To cite this version:}

Sandra Hélinck, Marie-Claire Perello, Pawinee Deetae, Gilles de Revel, Henry-Eric Spinnler. Debaryomyces hansenii, Proteus vulgaris, Psychrobacter sp and Microbacterium foliorum are able to produce biogenic amines. Dairy Science \& Technology, 2013, 93 (2), pp.191 - 200. 10.1007/s13594-012-0102-5 . hal-01003319

\section{HAL Id: hal-01003319 \\ https://hal.science/hal-01003319}

Submitted on 29 May 2020

HAL is a multi-disciplinary open access archive for the deposit and dissemination of scientific research documents, whether they are published or not. The documents may come from teaching and research institutions in France or abroad, or from public or private research centers.
L'archive ouverte pluridisciplinaire HAL, est destinée au dépôt et à la diffusion de documents scientifiques de niveau recherche, publiés ou non, émanant des établissements d'enseignement et de recherche français ou étrangers, des laboratoires publics ou privés. 


\title{
Debaryomyces hansenii, Proteus vulgaris, Psychrobacter sp. and Microbacterium foliorum are able to produce biogenic amines
}

\author{
Sandra Helinck • Marie-Claire Perello • Pawinee Deetae • \\ Gilles de Revel • Henry-Eric Spinnler
}

Received: 28 June 2012 / Revised: 15 November 2012 / Accepted: 16 November 2012 / Published online: 24 January 2013

(C) INRA and Springer-Verlag France 2013

\begin{abstract}
The occurrence of biogenic amines (BAs) produced by the microbiota of fermented foods is a source of health concern. The three bacteria Microbacterium foliorum, Proteus vulgaris and Psychrobacter sp. and the yeast Debaryomyces hansenii, isolated from surface-ripened cheeses, are known to contribute to their aromatic properties. The potential of each of these strains to produce BAs was investigated, both in pure cultures of each bacterium in a laboratory medium supplemented with amino acids and in mixed cultures with $D$. hansenii in a model cheese during the ripening process. BAs were quantified using HPLC. In the laboratory medium, all microbial strains produced at least one biogenic amine. P. vulgaris produced the highest amount of BAs, mainly putrescine and isoamylamine, with a total of $195 \mathrm{mg} . \mathrm{L}^{-1}$. In all of the model cheeses, the highest levels of BAs were determined at the end of ripening. With D. hansenii and M. foliorum, the total levels
\end{abstract}

\footnotetext{
S. Helinck $(\bowtie) \cdot$ P. Deetae $\cdot$ H.-E. Spinnler

AgroParisTech, UMR 782 Génie et Microbiologie des Procédés Alimentaires, 78850 Thiverval-

Grignon, France

e-mail: sandra.helinck@agroparistech.fr

S. Helinck $\cdot$ P. Deetae $\cdot$ H.-E. Spinnler

INRA, UMR 782 Génie et Microbiologie des Procédés Alimentaires, 78850 Thiverval-Grignon, France
}

M.-C. Perello • G. de Revel

Univ. Bordeaux, ISVV, EA 4577 Oenologie, 33882 Villenave d'Ornon, France

M.-C. Perello • G. de Revel

INRA, ISVV, USC 1366 Oenologie, 33882 Villenave d'Ornon, France

P. Deetae

Food Technology Program, Mahidol University, Kanchanaburi Campus Saiyok, Kanchanaburi 71150, Thailand 
of BAs were below $10 \mathrm{mg} \cdot \mathrm{kg}^{-1}$ of cheese. Gram-negative bacteria, in association with $D$. hansenii, produced up to $25 \mathrm{mg} . \mathrm{kg}^{-1}$ of BAs. Histamine was produced when Psychrobacter sp. was present, and isoamylamine, when P. vulgaris was present in the cheese ecosystem. Though these strains are able to catabolise amino acids into flavour compounds, they are also able to produce BAs, particularly putrescine, isoamylamine and histamine, showing the simultaneous expression of the two catabolic pathways. This study is a preliminary work on the assessment of the impact of all ripening microorganisms on the sanitary quality of cheese.

Keywords Biogenic amines $\cdot$ Cheese $\cdot$ Ripening microbiota $\cdot$ Putrescine Gram-negative bacteria

\section{Introduction}

Smear-ripened cheeses such as Gubbeen or Livarot are characterised by a succession of microbial communities on their surface during a maturation stage (Mounier et al. 2009; Larpin-Laborde et al. 2011). The microbial diversity of smear cheeses including yeasts, Gram-positive and Gram-negative bacteria has been extensively investigated. The surface yeast microbiota is dominated by Debaryomyces hansenii, Geotrichum candidum and Kluyveromyces sp. (LarpinLaborde et al. 2011). The most common bacterial genera are Brevibacterium, Corynebacterium and Arthrobacter spp. Gram-negative bacteria, including Psychrobacter, Proteus and Halomonas, have also been frequently identified in cheeses (Mounier et al. 2009). These adventitious bacteria come from raw milk or from the cheese-making environment and may constitute more than $40 \%$ of the bacterial microbiota of some smear cheese surfaces (Mounier et al. 2009; Larpin-Laborde et al. 2011). These microbial communities play an important role in the ripening process because they contribute to the aspect, texture, colour and aroma of cheeses (Deetae et al. 2009; Irlinger and Mounier 2009).

However, some bacteria isolated from cheeses, such as Enterobacteriaceae strains, were able to produce biogenic amines (Marino et al. 2000; Chaves-Lopez et al. 2006; Pattono et al. 2008). Biogenic amines (BAs) are low-molecular-weight nitrogenous compounds formed through the microbial decarboxylation of amino acids. They can be found in fish, meat and fermented products: wine, dairy, meat, soy sauce and vegetables (European Food Safety Authority 2011). Tyramine, histamine, putrescine, cadaverine and phenylethylamine are generally considered to be the major BAs found in cheeses (Novella-Rodriguez et al. 2003; Linares et al. 2011). In some cheeses such as hard cheeses, blue or smear-ripened cheeses, more than 1,000 mg of total BAs has been detected per kilogramme of cheese (Linares et al. 2011; Komprda et al. 2012). The consumption of foods containing high levels of BAs, particularly histamine, can be responsible of serious human health problems (Maintz and Novak 2007). The European Food Safety Authority recommended that it should be confirmed that microorganisms intended to be used as starter cultures in any fermented food do not produce BAs (European Food Safety Authority 2011). In cheeses, BAsproducing microorganisms may be part of starter cultures such as lactic acid bacteria (Linares et al. 2011) and may be associated with raw milk, as in the case 
of Enterobacteriaceae and Pseudomonas sp. (Marino et al. 2000, 2008; Martuscelli et al. 2005). The ability to form BAs has been extensively studied for lactic acid bacteria and Enterobacteriaceae (Ladero et al. 2008; Marino et al. 2000; Pattono et al. 2008). Because of the complexity of the microbial ecosystem, studies on the abilities of other species of Gram-negative or Gram-positive strains to generate BAs are still relatively rare. Some Gram-negative strains isolated from different French dairy sources (milk and different cheeses) were recently assessed for potential risk factors such as volatile amine production in vitro (Coton et al. 2012). Potential decarboxylase activities involved in the production of at least one biogenic amine were found in 111 isolates (out of 173 tested) after screening isolates on specific medium.

It has been previously shown that three bacteria isolated from different French surface-ripened cheeses, a Gram-positive bacterium, Microbacterium foliorum, and two Gram-negative bacteria, Proteus vulgaris and Psychrobacter sp., were able to produce large amounts of volatile compounds that significantly contribute to cheese quality (Deetae et al. 2009). However, the other characteristics related to the use of these strains as ripening cultures, such as BAs production, have not yet been evaluated. In the present study, P. vulgaris, Psychrobacter sp., M. foliorum and D. hansenii were characterised in regards to the production of BAs in liquid medium and in a model cheese.

\section{Materials and methods}

\subsection{Microorganisms}

The microorganisms used in this study were P. vulgaris 1 M10, Psychrobacter sp. 580, M. foliorum C45 and D. hansenii 304. They were isolated from French cheeses, and they belong to the collections of both the UMR GMPA (INRA Grignon, Thiverval-Grignon, France) and the UCMA (Laboratoire de Microbiologie Alimentaire, University of Caen, France). The stock cultures were stored at $-80{ }^{\circ} \mathrm{C}$.

\subsection{Biogenic amines production in vitro and in model cheese}

Strains were inoculated in brain heart infusion (BHI) medium (Biokar Diagnostics, Beauvais, France), supplemented with $0.5 \%$ of amino acids (L-histidine, L-lysine, Larginine, L-phenylalanine, L-tryptophan, L-ornithine) and $0.1 \%$ of L-tyrosine. All amino acids were obtained from Sigma. Culture media were incubated at $25{ }^{\circ} \mathrm{C}$ for $48 \mathrm{~h}$. After incubation, cells were removed by centrifugation, and supernatants were stored at $-20^{\circ} \mathrm{C}$ until analysis. Non-inoculated medium was used as a control. For each culture, the reproducibility of the experiments was evaluated in triplicate.

Model cheeses were prepared under aseptic conditions as previously described (Deetae et al. 2009). Briefly, cheese curds were mixed (65\% wet weight) with $35 \%$ sterile brine ( $\left.48.5 \mathrm{~g} \mathrm{NaCl} . \mathrm{L}^{-1}\right)$ using a laboratory blender to obtain a homogenous content of $1.7 \%$ salt. The cheese slurry obtained was then heated at $115^{\circ} \mathrm{C}$ for $30 \mathrm{~min}$ to kill lactic acid bacteria and other possible contaminants. After cooling, the cheese slurry was homogenised under aseptic conditions, and $100 \mathrm{~g}$ was aseptically transferred to $250-\mathrm{mL}$ 
sterile Erlenmeyer flasks. Each bacterial strain was cultivated in association with $D$. hansenii 304 in order to obtain a deacidification of the model cheese (Deetae et al. 2009). Bacteria and yeast cultures were inoculated in the cheese slurry at concentrations of $10^{6}$ and $10^{5}$ cfu.g ${ }^{-1}$, respectively, and incubated at $14^{\circ} \mathrm{C}$ under aerobic conditions on a rotary shaker at $130 \mathrm{rpm}$ for 41 days. Non-inoculated and yeast-inoculated cheese media were used as controls in this study. Samples were taken at regular time intervals during incubation for model cheese analysis. For each culture, the reproducibility of the experiments was evaluated in triplicate. Samples were stored at $-20{ }^{\circ} \mathrm{C}$ until analysis.

\subsection{Microbiological counts}

Viable cell counts of bacteria and yeast were carried out on BHI agar and YEGC (Chloramphenicol Glucose Agar, Biokar), respectively. Agar plates were incubated at $25^{\circ} \mathrm{C}$ for 2 to 3 days.

\section{$2.4 \mathrm{pH}$ measurements and amino acid analysis}

Three independent values of $\mathrm{pH}$ were obtained for each sample, and means and standard deviations were calculated. Free amino acids were extracted from model cheeses and analysed as previously described (Deetae et al. 2009).

\subsection{Biogenic amine determination}

Sample preparation and amines extraction were performed as previously described (Martuscelli et al. 2005). Supernatants of microbial cultures carried out in BHI medium were mixed with $0.1 \mathrm{~N} \mathrm{HCl}(1: 1, v / v)$. The mixture was centrifuged again, filtered $(0.45 \mu \mathrm{m})$ and stored at $-20{ }^{\circ} \mathrm{C}$ until BAs analysis. Cheese samples $(10 \mathrm{~g})$ were homogenised in $20 \mathrm{~mL}$ of $0.1 \mathrm{~N} \mathrm{HCl}$ and centrifuged $\left(12,000 \times \mathrm{g}, 20 \mathrm{~min}, 4^{\circ} \mathrm{C}\right)$. The supernatant was recovered, and the extraction was performed again with $20 \mathrm{~mL}$ of $0.1 \mathrm{~N}$ $\mathrm{HCl}$. The two acid extracts were then mixed and made up to $40 \mathrm{~mL}$ with $0.1 \mathrm{~N} \mathrm{HCl}$. This extract was filtered $(0.45 \mu \mathrm{m})$ and stored at $-20{ }^{\circ} \mathrm{C}$ until analysis of the BAs.

Separation, identification and quantification of BAs in samples were performed with HPLC following the procedure described by Pereira Monteiro and Bertrand (1994). An HP 1050 HPLC instrument from Agilent Technologies (Massy, France) was used. The excitation and emission wavelengths were 350 and $445 \mathrm{~nm}$, respectively. A Lichrospher RP-18 $(5 \mu \mathrm{m})$ HPLC cartridge $[12 \times 5 \mathrm{~mm}$ internal diameter (i.d.)] associated with a LiChrospher RP-18 guard column $(4 \times 5 \mathrm{~mm}$ i.d.) was used. A standard solution containing a mixture of histamine, tyramine, tryptamine, phenylethylamine, ethylamine, methylamine, putrescine, isoamylamine and cadaverine $\left(500 \mathrm{mg} . \mathrm{L}^{-1}\right.$ each $)$ in a hydroalcoholic solution $(50 \% v / v)$ was used, after different dilutions, to quantify the BAs present in the samples. The range of linearity tested was 0 to $30 \mathrm{mg} . \mathrm{L}^{-1}$ for each BA. The internal standard solution was a 2.5 g.L $\mathrm{L}^{-1}$ butylamine hydroalcoholic solution $(50 \% \mathrm{v} / \mathrm{v})$.

\subsection{Statistical analysis}

All experiments were carried out in triplicate independent cultures of the same types, and all results were reported as means \pm standard deviation. An analysis of variance 
(one-way ANOVA) was performed. A Student-Newman-Keuls test was applied on the individual variables to compare means and to assess their significant differences (at significant level $\alpha \leq 0.05$ ). Distinct letters ( $a, b, c)$ were assigned to significantly different groups.

\section{Results and discussion}

\subsection{Biogenic amine production in a liquid medium}

High counts of microorganisms were found in the culture medium after $48 \mathrm{~h}$ of incubation under aerobic conditions. The microbial population was $1.6 \pm 0.1 \times$ $10^{9}$ cfu. $\mathrm{mL}^{-1}$ for D. hansenii, $1.9 \pm 0.5 \times 10^{9}$ cfu. $\mathrm{mL}^{-1}$ for M. foliorum, $3.0 \pm 0.2 \times$ $10^{9}$ cfu. $\mathrm{mL}^{-1}$ for Psychrobacter sp. and $4.6 \pm 0.4 \times 10^{9}$ cfu. $\mathrm{mL}^{-1}$ for P. vulgaris.

Biogenic amine diversity and levels were different depending on the species (Table 1). The highest levels of BAs were produced by $P$. vulgaris, with a total of $195 \mathrm{mg} . \mathrm{L}^{-1}$. All the strains produced putrescine and, in particular, P. vulgaris, with a level of $145 \mathrm{mg} \cdot \mathrm{L}^{-1}$. This is in accordance with previous results obtained with three strains of $P$. vulgaris isolated from dairy products. These strains were able to produce putrescine ( 4 to $\left.450 \mathrm{mg} . \mathrm{L}^{-1}\right)$, cadaverine $\left(0.5\right.$ to $5 \mathrm{mg} . \mathrm{L}^{-1}$ ) and histamine ( 0 to $99 \mathrm{mg} . \mathrm{L}^{-1}$ ) at $37{ }^{\circ} \mathrm{C}$, in a liquid medium supplemented with amino acids (Pattono et al. 2008). The highest histamine-forming microorganism was Psychrobacter sp., with a level of $18 \mathrm{mg} \cdot \mathrm{L}^{-1}$. Few studies are available on the production of BAs by Psychrobacter sp. strains. One strain of $P$. celer produced $26 \mathrm{mg} . \mathrm{L}^{-1}$ of histamine in a laboratory medium containing histidine (Coton et al. 2012), and a strain of $P$. immobilis was not able to produce histamine in a laboratory medium (Özogul and Özogul 2007).

\subsection{Growth of microorganisms and amino acid levels in model cheeses}

All microorganisms were able to grow in model cheeses, and final populations were higher than $10^{9}$ cfu.g ${ }^{-1}$ (Table 2). Yeast, alone or in co-culture with bacterial strains,

Table 1 Biogenic amines production (in milligramme per litre) by microbial strains incubated in BHI medium during $48 \mathrm{~h}$ at $25^{\circ} \mathrm{C}$

\begin{tabular}{lrllllrr}
\hline & HIST & TYR & PHA & PUT & ISO & CAD & Total \\
\hline Control & $0.33 \pm 0.02$ & $0.79 \pm 0.06$ & $0.11 \pm 0.01$ & $0.30 \pm 0.10$ & $0.11 \pm 0.05$ & 0.00 & $1.65 \mathrm{a}$ \\
M. foliorum & $11.18 \pm 0.11$ & $0.40 \pm 0.03$ & $0.30 \pm 0.04$ & $0.82 \pm 0.19$ & $0.33 \pm 0.01$ & 0.00 & $13.03 \mathrm{a}$ \\
P. vulgaris & $0.11 \pm 0.03$ & $0.31 \pm 0.08$ & $20.67 \pm 4.52$ & $145.00 \pm 29.78$ & $29.00 \pm 6.20$ & 0.00 & $195.09 \mathrm{~b}$ \\
Psychrobacter sp. & $18.27 \pm 2.92$ & $0.74 \pm 0.16$ & $0.43 \pm 0.08$ & $1.25 \pm 0.17$ & $0.16 \pm 0.07$ & 0.00 & $20.85 \mathrm{a}$ \\
D. hansenii & $5.68 \pm 0.21$ & $1.51 \pm 0.02$ & $0.12 \pm 0.03$ & $3.86 \pm 0.30$ & $0.17 \pm 0.06$ & $5.07 \pm 0.19$ & $16.40 \mathrm{a}$ \\
\hline
\end{tabular}

Results are presented as the means and standard deviation of three independent cultures of the same strain. The means (total BAs) that have different letters are significantly different

HIST histamine, TYR tyramine, PHA phenylethylamine, PUT putrescine, ISO isoamylamine, CAD cadaverine 
Table 2 Microbiological counts, $\mathrm{pH}$, total free amino acid concentrations and total biogenic amines concentrations during the ripening of different model cheeses over 41 days at $14{ }^{\circ} \mathrm{C}$

\begin{tabular}{lrlllr}
\hline Model cheeses & Days & $\begin{array}{l}\text { Microbiological } \\
\text { counts } \\
\left(\mathrm{cfu}^{-1}\right)\end{array}$ & $\mathrm{pH}$ & $\begin{array}{l}\text { Total free amino } \\
\text { acids } \\
\left(\mathrm{mg}^{-1} \mathrm{~kg}^{-1}\right)\end{array}$ & $\begin{array}{c}\text { Total BAs } \\
\left(\mathrm{mg}^{-1} \mathrm{~kg}^{-1}\right)\end{array}$ \\
\hline D. hansenii & 0 & $9.8( \pm 1.3) 10^{4}$ & $4.7 \pm 0.1$ & $423 \pm 8 \mathrm{a}$ & $3.8 \pm 0.1 \mathrm{a}$ \\
& 12 & $5.3( \pm 1.1) 10^{8}$ & $6.2 \pm 0.1$ & $\mathrm{ND}$ & $5.2 \pm 0.8 \mathrm{a}$ \\
& 21 & $2.2( \pm 1.2) 10^{9}$ & $6.2 \pm 0.1$ & $266 \pm 39 \mathrm{a}$ & $5.1 \pm 0.8 \mathrm{a}$ \\
& 41 & $8.5( \pm 1.1) 10^{8}$ & $7.3 \pm 0.3$ & $1536 \pm 677 \mathrm{~b}$ & $9.1 \pm 2.0 \mathrm{~b}$ \\
D. hansenii and M. foliorum & 0 & $8.9( \pm 7.8) 10^{4}$ & $4.7 \pm 0.1$ & $402 \pm 11 \mathrm{a}$ & $3.8 \pm 0.1 \mathrm{a}$ \\
& 12 & $1.6( \pm 0.2) 10^{10}$ & $6.2 \pm 0.1$ & $\mathrm{ND}$ & $4.3 \pm 0.8 \mathrm{a}$ \\
& 21 & $6.4( \pm 1.8) 10^{10}$ & $6.2 \pm 0.1$ & $619 \pm 24 \mathrm{~b}$ & $12.7 \pm 2.3 \mathrm{~b}$ \\
& 41 & $1.6( \pm 0.3) 10^{11}$ & $7.5 \pm 0.5$ & $7689 \pm 1962 \mathrm{c}$ & $10.5 \pm 2.0 \mathrm{~b}$ \\
& 0 & $4.9( \pm 0.9) 10^{5}$ & $4.7 \pm 0.1$ & $423 \pm 8 \mathrm{a}$ & $3.8 \pm 0.1 \mathrm{a}$ \\
& 12 & $2.7( \pm 0.2) 10^{8}$ & $6.2 \pm 0.1$ & $\mathrm{ND}$ & $2.6 \pm 0.9 \mathrm{a}$ \\
& 21 & $5.7( \pm 0.9) 10^{8}$ & $6.2 \pm 0.1$ & $236 \pm 41 \mathrm{~b}$ & $6.4 \pm 1.6 \mathrm{a}$ \\
& 41 & $6.1( \pm 1.6) 10^{9}$ & $6.0 \pm 0.2$ & $363 \pm 81 \mathrm{a}$ & $25.1 \pm 3.8 \mathrm{~b}$ \\
& 0 & $4.0( \pm 1.5) 10^{5}$ & $4.7 \pm 0.1$ & $439 \pm 9 \mathrm{a}$ & $3.7 \pm 0.1 \mathrm{a}$ \\
& 12 & $3.2( \pm 0.9) 10^{5}$ & $6.2 \pm 0.1$ & $\mathrm{ND}$ & $3.4 \pm 0.8 \mathrm{a}$ \\
& 21 & $1.4( \pm 0.2) 10^{7}$ & $6.2 \pm 0.1$ & $220 \pm 43 \mathrm{~b}$ & $5.5 \pm 2.1 \mathrm{a}$ \\
& 41 & $4.4( \pm 2.6) 10^{9}$ & $7.2 \pm 0.1$ & $259 \pm 46 \mathrm{~b}$ & $25.8 \pm 4.4 \mathrm{~b}$ \\
\hline
\end{tabular}

Results are presented as the means and standard deviation of three independent cultures. For one model cheese, the means that have different letters are significantly different

$N D$ not determined

showed rapid growth with a maximal population after 6 days. The growth of bacterial strains began after day 6 or 12 of ripening.

The biosynthesis of BAs in foods requires the availability of the substrate of the decarboxylases, the free amino acids. As shown in Table 2, significant increases in the content of free amino acids were observed throughout the 41-day ripening period in model cheeses containing $D$. hansenii (threefold) and the co-culture $D$. hansenii/M. foliorum (17-fold). On the contrary, no significant modification occurred in the free amino acid content of the model cheeses containing the co-cultures $D$. hansenii/ Psychrobacter sp. or D. hansenii/P. vulgaris. However, some previous studies have shown that $P$. vulgaris has a higher capacity for hydrolysing casein or peptides (Deetae et al. 2009). In most cheeses, the amino acid accumulation is desired. A recent work on Cheddar cheese shows the possible modulation of this accumulation through the choice of protease (Kilcawley et al. 2012). In fact, amino acids are transitory compounds during ripening because they result from casein degradation and further transformation into aroma compounds and BAs; the amino acid concentration observed is a balance between their production through protease and peptidase activities and their breakdown through transamination and decarboxylation pathways. The amino acid breakdown is slower than the production, leading to an amino acid accumulation in the cheese during cheese ripening, but the types of amino acids available in cheese depend on the expression of the different peptidases activities. It is therefore difficult to relate the total 
level of amino acids and the concentration of BAs. However, for the bacteria tested in this study, the amino acid accumulation (e.g. by P. vulgaris) seems not only favourable to the synthesis of aroma compounds (Deetae et al. 2009) but also to the production of BAs. Even if all these strains are able to produce aroma compounds from amino acids through the Ehrlich pathway (Deetae et al. 2009), a competition between the transamination and the decarboxylation activities for the amino acids is probable.

\subsection{Biogenic amine production in model cheeses}

BAs were detected in all the model cheeses. As shown in Table 2, the total amount of BAs increased after day 21 of ripening and was the highest at the end of ripening. This increase in concentration during ripening is in accordance with previous studies (Komprda et al. 2008; Martuscelli et al. 2005; Novella-Rodriguez et al. 2004). Maximal levels of BAs detected in the five model cheeses analysed were between 10 and $25 \mathrm{mg} \cdot \mathrm{kg}^{-1}$ of cheese. In the control cheese, the BAs level did not vary during the ripening process (below $4 \mathrm{mg} \cdot \mathrm{kg}^{-1}$ ). The highest levels of BAs were detected when $P$. vulgaris or Psychrobacter sp. was present in the model cheeses. The yeast, $D$. hansenii 304, usually inoculated as ripening microbiota, produced $10 \mathrm{mg}$ of total BAs $\bullet \mathrm{kg}$ of cheese, mainly putrescine (Fig. 1). It was previously shown that three out of 13 strains of D. hansenii tested, isolated from Pecorino

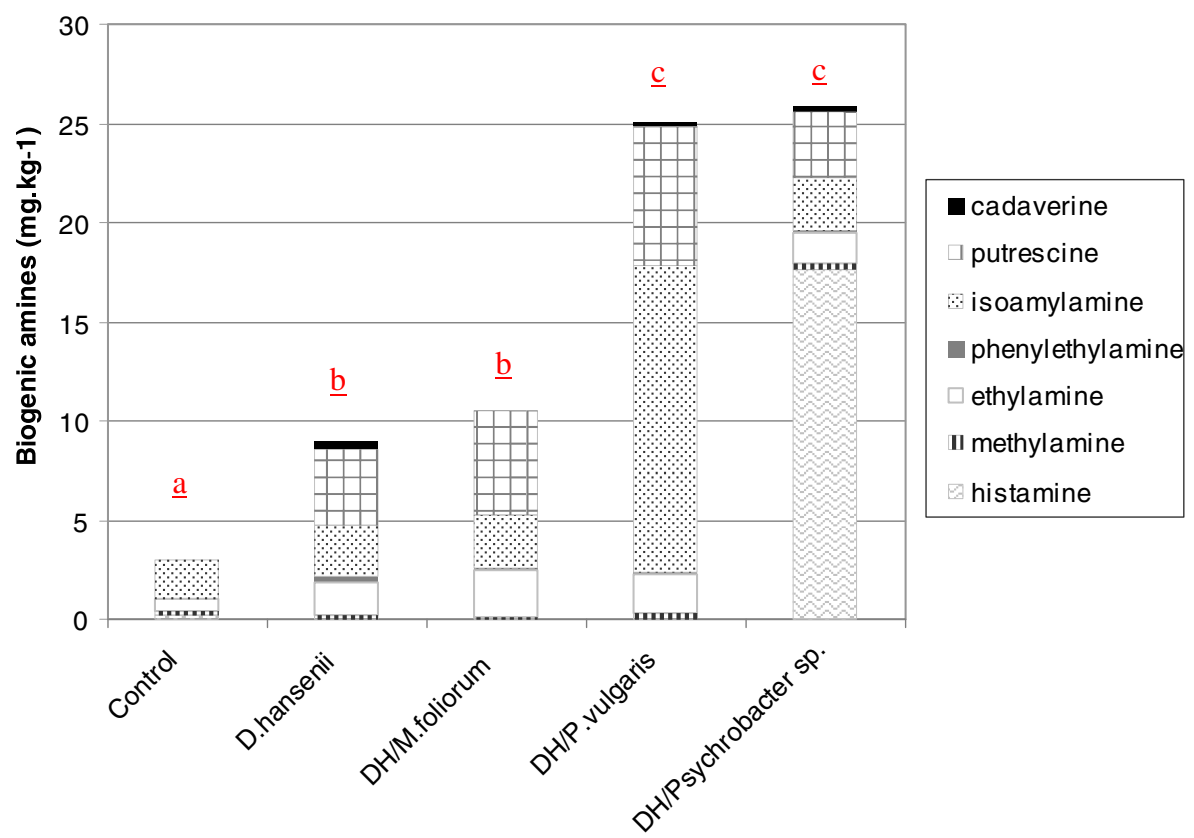

Fig. 1 Levels of biogenic amines (in milligramme per kilogramme) detected in different model cheeses at the end of ripening. Control model cheese without inoculation; $D$. hansenii model cheese inoculated with D. hansenii; DH/M. foliorum model cheese inoculated with $D$. hansenii and M. foliorum; DH/P. vulgaris model cheese inoculated with $D$. hansenii and P. vulgaris; DH/Psychrobacter $s p$. model cheese inoculated with D. hansenii and Psychrobacter sp. Results are the mean of three independent cultures. The means that have different letters are significantly different 
Crotonese cheeses, were able to produce putrescine and histamine in a specific agar medium (Gardini et al. 2006).

Among the nine BAs analysed, only histamine, putrescine, ethylamine and isoamylamine were detected in significant amounts in the model cheeses. Phenylethylamine, methylamine and cadaverine were detected as traces (values between 0.1 and $0.4 \mathrm{mg} \cdot \mathrm{kg}^{-1}$ ); tyramine and tryptamine were not detected. Quantities and distributions of BAs, at the end of ripening, depend on the microbial composition of the model cheese, as shown in Fig. 1. It is important to observe that the ability of the four strains studied to produce BAs in BHI medium did not reflect their production in a model cheese. Indeed, environmental factors such as $\mathrm{pH}, \mathrm{NaCl}$ concentration, time and temperature of ripening and availability of the substrate amino acids are known to influence BAs production (Vicentini and Giacco 2006; Linares et al. 2012). A low pH is a key parameter of BAs production, and at the opposite, a high salt content reduced the amount of BAs production. Moreover, the consequences of their interaction have to be studied. Therefore, in situ confirmation of BAs production is necessary.

Histamine was only detected in model cheeses containing the co-culture $D$. hansenii/Psychrobacter sp., with a level of $17.6 \pm 1.1 \mathrm{mg} \cdot \mathrm{kg}^{-1}$ of cheese $(68 \%$ of total BAs). Histidine concentration was similar during ripening for all the model cheeses (data not shown). Histamine has been frequently detected, with a high variability of concentrations, in ripened cheeses (Novella-Rodriguez et al. 2003; European Food Safety Authority 2011). This production was associated with the occurrence of Enterobacteriaceae and/or Enterococcus. It is the first report of the ability of Psychrobacter sp. to produce histamine in a model cheese.

Putrescine was detected in all model cheeses and was the most abundant BA found in model cheeses containing $D$. hansenii alone and the co-culture $D$. hansenii/M. foliorum, with a proportion of 41 and 50\%, respectively. Generally, high counts of Enterobacteriaceae in cheese during ripening could be correlated with high concentrations of putrescine, cadaverine and histamine (Chaves-Lopez et al. 2006; Marino et al. 2000; Pattono et al. 2008). For example, putrescine has been detected in raw ewe's milk Terrincho cheese with levels of 80 to $440 \mathrm{mg} \cdot \mathrm{kg}^{-1}$ of dry matter (Pintado et al. 2008) and in goat cheeses made from pasteurised milk with levels of 8 to $14 \mathrm{mg} \cdot \mathrm{kg}^{-1}$ of dry matter (Novella-Rodriguez et al. 2004). The microbiota of these cheeses contained high numbers of species implicated in BAs production such as Lactococci, Enterococci and Enterobacteriaceae. Ornithine is the amino acid precursor of putrescine, and its concentration in all model cheeses decreased during the 41-day ripening period (data not shown), which is in agreement with the increase in putrescine. Putrescine could also be formed in some bacteria by another pathway that involves the deamination of agmatine (Landete et al. 2008). No information is available on the pathway for putrescine production in the ripening microorganisms used in this study.

Isoamylamine was detected in all model cheese inoculated with ripening microbiota and in the control cheese. It is assumed that this BA was initially produced by the strains of Lactococcus lactis used for the coagulation step. High production of isoamylamine was also observed in cheeses inoculated with P. vulgaris, with a value of $15.5 \pm$ $3.4 \mathrm{mg} \cdot \mathrm{kg}^{-1}$ ( $62 \%$ of total BAs). The production of isoamylamine has rarely been investigated in cheeses or in bacteria isolated from dairy products. Leucine is known to be the amino acid precursor of this BA, and its concentration in cheese significantly decreased during the 41-day ripening period when $P$. vulgaris was present. 


\section{Conclusion}

These data highlighted the capacity of indigenous and environmental microbial populations of cheese to produce BAs. It is necessary to investigate the ability of Grampositive and Gram-negative bacteria frequently found in cheese to produce biogenic amines. If the use of a synthetic media allows to easily screen a large number of strains, the use of model cheeses seems necessary to confirm the properties because of the interactions between bacteria, yeasts and curd. Moreover, the catabolism of BAs could be interesting to study in order to select strains able to degrade BAs.

\section{References}

Chaves-Lopez C, De Angelis M, Martuscelli M, Serio A, Paparella A, Suzzi G (2006) Characterization of the Enterobacteriaceae isolated from an artisanal Italian ewe's cheese (Pecorino Abruzzese). J Appl Microbiol 101:353-360

Coton M, Delbès-Paus C, Irlinger F, Desmasures N, Le Flèche A, Stahl V, Montel MC, Coton E (2012) Biodiversity and assessment of potential risk factors of Gram-negative isolates associated with French cheeses. Food Microbiol 29:88-98

Deetae P, Bonnarme P, Spinnler HE, Helinck S (2009) Growth and aroma contribution of Microbacterium foliorum, Proteus vulgaris and Psychrobacter sp. during ripening in a cheese model medium. Appl Microbiol Biotechnol 82:169-177

European Food Safety Authority (2011) Scientific opinion on risk based control of biogenic amine formation in fermented foods. EFSA J 9:2393

Gardini F, Tofalo R, Belletti N, Iucci L, Suzzi G, Torriani S, Guerzoni ME, Lanciotti R (2006) Characterization of yeasts involved in the ripening of Pecorino Crotonese cheese. Food Microbiol 23:641-648

Irlinger F, Mounier J (2009) Microbial interactions in cheese: implications for cheese quality and safety. Curr Opin Biotechnol 20:142-148

Kilcawley K, Nongonierma AB, Hannon JA (2012) Evaluation of commercial enzyme systems to accelerate Cheddar cheese ripening. Int Dairy J 26:50-57

Komprda T, Burdychova R, Dohnal V, Cwikova O, Sladkova P (2008) Some factors influencing biogenic amines and polyamines content in Dutch-type semi-hard cheese. Eur Food Res Technol 227:29-36

Komprda T, Rejchrtova E, Sladkova P, Zemanek L, Sladkova P (2012) Effect of some external factors on the content of biogenic amines and polyamines in a smear-ripened cheese. Dairy Sci Technol 92:367-382

Ladero V, Linares DM, Fernandez M, Alvarez MA (2008) Real time quantitative PCR detection of histamine-producing lactic acid bacteria in cheese: Relation with histamine content. Food Res Int 41:1015-1019

Landete JM, Arena ME, Pardo I, Manca de Nadra MC, Ferrer S (2008) Comparative survey of putrescine production from agmatine deamination in different bacteria. Food Microbiol 25:882-887

Larpin-Laborde S, Imran M, Bonaiti C, Bora N, Gelsomino R, Goerges S, Irlinger F, Goodfellow M, Ward AC, Vancanneyt M, Swings J, Scherer S, Guéguen M, Desmasures N (2011) Surface microbial consortia from Livarot, a French smear-ripened cheese. Can J Microbiol 57:657-660

Linares DM, Martin MC, Ladero V, Alvarez MA, Fernandez M (2011) Biogenic amines in dairy products. Crit Rev Food Sci Nutr 51:691-703

Linares DM, del Rio B, Ladero V, Martinez N, Martin MC, Alvarez MA (2012) Factors influencing biogenic amines accumulation in dairy products. Front Microbiol 180:1-10

Maintz L, Novak N (2007) Histamine and histamine intolerance. Am J Clin Nutr 85:1185-1196

Marino M, Maifreni M, Moret S, Rondini G (2000) The capacity of Enterobacteriaceae species to produce biogenic amines in cheese. Lett Appl Microbiol 31:169-173

Marino M, Maifreni M, Bartolomeoli I, Rondinini G (2008) Evaluation of amino acid-decarboxylative microbiota throughout the ripening of an Italian PDO cheese produced using different manufacturing practices. J Appl Microbiol 105:540-549

Martuscelli M, Gardini F, Torriani S, Mastrocola D, Serio A, Chaves-Lopez C, Schirone M, Suzzi G (2005) Production of biogenic amines during the ripening of Pecorino Abruzzese cheese. Int Dairy J 15:571-578 
Mounier J, Monnet C, Jacques N, Antoinette A, Irlinger F (2009) Assessment of the microbial diversity at the surface of Livarot cheese using culture-dependent and independent approaches. Int $\mathrm{J}$ Food Microbiol 133:31-37

Novella-Rodriguez S, Veciana-Nogués MT, Izquierdo-Pulido M, Vidal-Carou MC (2003) Distribution of biogenic amines and polyamines in cheese. J Food Sci 68:750-755

Novella-Rodriguez S, Veciana-Nogués MT, Roig-Sagués AX, Trujillo-Mesa AJ, Vidal-Carou MC (2004) Evaluation of biogenic amines and microbial counts throughout the ripening of goat cheeses from pasteurized and raw milk. J Dairy Res 71:245-252

Özogul F, Özogul Y (2007) The ability of biogenic amines and ammonia production by single bacterial cultures. Eur Food Res Technol 225:385-394

Pattono D, Grassi MA, Civera T (2008) Production of biogenic amines by some Enterobacteriaceae strains isolated from dairy products. Ital J Food Sci 20:411-417

Pereira Monteiro MJ, Bertrand A (1994) Validation of a dosing method. Application to the analysis of biogenic amines in wine. Bull OIV 765:917-962

Pintado AIE, Pinho O, Ferreira IMPLVO, Pintando MME, Gomes AMP, Malcata FX (2008) Microbiological, biochemical and biogenic amine profiles of Terrincho cheese manufactured in several dairy farms. Int Dairy J 18:631-640

Vicentini A, Giaccio M (2006) Technological factors influencing the formation of biogenic amines in cheese: a review. J Commod Sci Technol Qual 45:99-118 